\title{
Corrigendum: Overcoming Barriers to Successfully Commercializing Carbon Dioxide Utilization
}

\section{OPEN ACCESS}

Edited and reviewed by:

Katy Armstrong,

University of Sheffield,

United Kingdom

*Correspondence:

Marvin Kant

marvin.kant@tu-berlin.de

Specialty section:

This article was submitted to

Carbon Capture, Storage, and

Utilization,

a section of the journal

Frontiers in Energy Research

Received: 16 March 2018

Accepted: 04 April 2018

Published: 24 April 2018

Citation:

Kant M (2018) Corrigendum:

Overcoming Barriers to Successfully

Commercializing Carbon Dioxide

Utilization. Front. Energy Res. 6:31.

doi: 10.3389/fenrg.2018.00031

\section{Marvin Kant* \\ Department of Entrepreneurship and Innovation Management, Technische Universität Berlin, Berlin, Germany}

Keywords: sustainable entrepreneurship, sustainability transition, barriers to commercial success, $\mathrm{CO}_{2}$ utilization, new technology venture, commercialization, sustainability-oriented innovation, support system

\section{A corrigendum on}

Overcoming Barriers to Successfully Commercializing Carbon Dioxide Utilization by Kant, M. (2017). Front. Energy Res. 5:22. doi: 10.3389/fenrg.2017.00022

There was a mistake in the title of the $\mathrm{x}$ axis of Figure 5 as published (the sample size [n] was incorrect). The correct title of the $\mathrm{x}$ axis of Figure 5 is: "Percentage of new ventures in Canada and the USA reporting $(n=10)$." The author apologizes for the mistake. This error does not change the scientific conclusions of the article in any way.

The original article has been updated.

Conflict of Interest Statement: The author declares that the research was conducted in the absence of any commercial or financial relationships that could be construed as a potential conflict of interest.

Copyright (-) 2018 Kant. This is an open-access article distributed under the terms of the Creative Commons Attribution License (CC BY). The use, distribution or reproduction in other forums is permitted, provided the original author(s) and the copyright owner are credited and that the original publication in this journal is cited, in accordance with accepted academic practice. No use, distribution or reproduction is permitted which does not comply with these terms. 


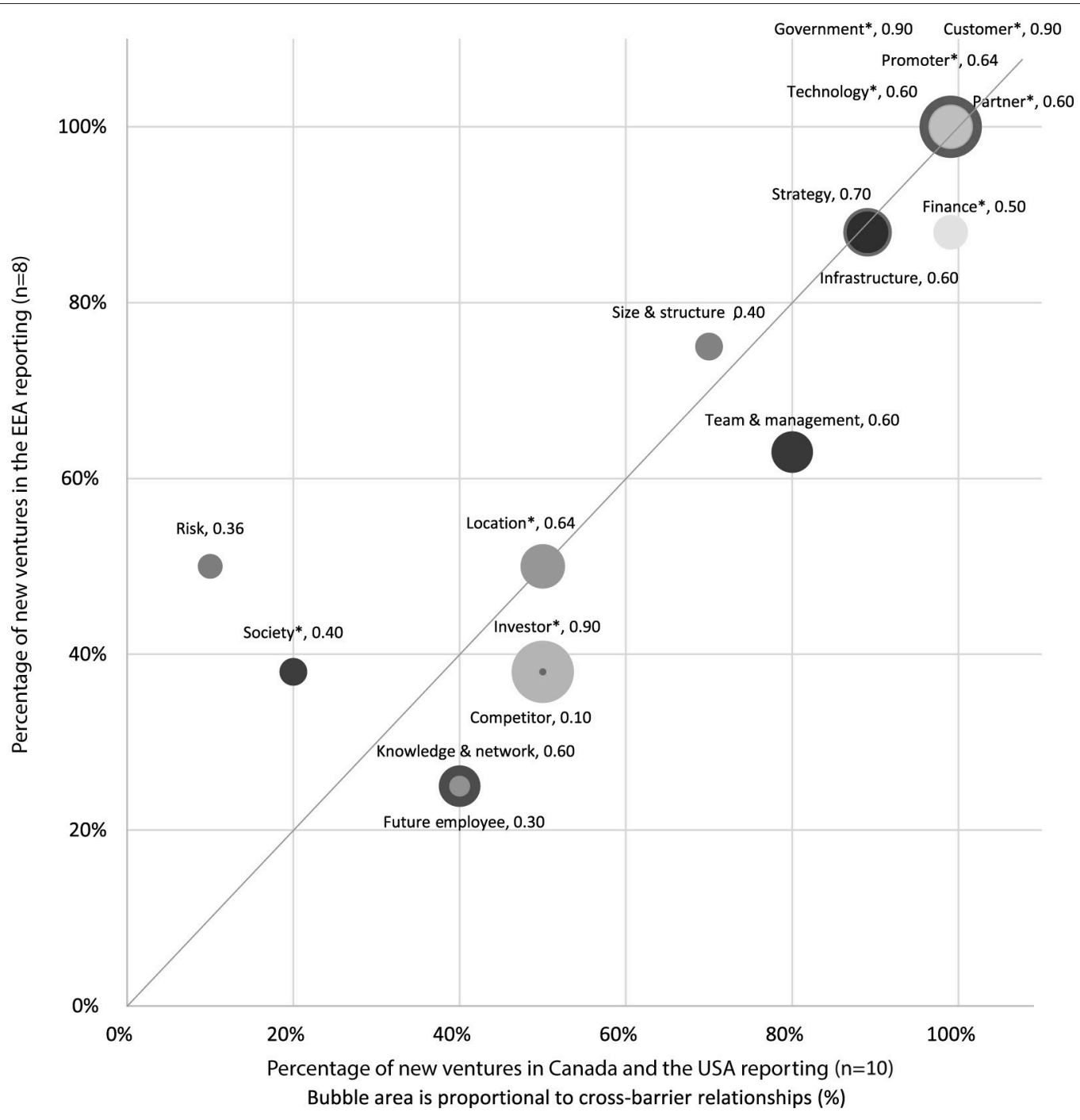

FIGURE 5 | Reported barrier category matrix: Canada and USA vs. EEA. *Perceived main barrier reported in category. 